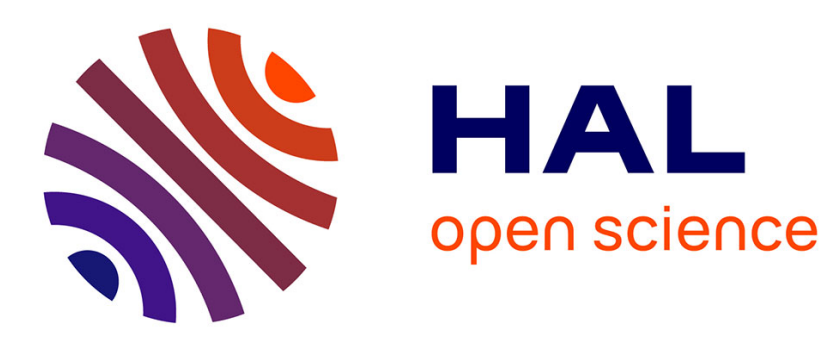

\title{
Biogeographic relationships of Pliocene and Pleistocene North-western African Mammals
}

\author{
Denis Geraads
}

\section{To cite this version:}

Denis Geraads. Biogeographic relationships of Pliocene and Pleistocene North-western African Mammals. Quaternary International, 2010, 212, pp.159-168. halshs-00477268

\section{HAL Id: halshs-00477268 \\ https://shs.hal.science/halshs-00477268}

Submitted on 28 Apr 2010

HAL is a multi-disciplinary open access archive for the deposit and dissemination of scientific research documents, whether they are published or not. The documents may come from teaching and research institutions in France or abroad, or from public or private research centers.
L'archive ouverte pluridisciplinaire HAL, est destinée au dépôt et à la diffusion de documents scientifiques de niveau recherche, publiés ou non, émanant des établissements d'enseignement et de recherche français ou étrangers, des laboratoires publics ou privés. 
Biogeographic relationships of Pliocene and Pleistocene North-western African Mammals

Denis GERAADS

CNRS - UPR 2147 - 44 rue de l'Amiral Mouchez - F-75014 PARIS

denis.geraads@evolhum.cnrs.fr

tel 33143135621

fax 33143135630

\begin{abstract}
North-western Africa, today included in the Palaearctic realm, is well separated from the Ethiopian province by the Sahara, but the distribution of large mammals shows that these biogeographic domains cannot simply be extrapolated to the late Cenozoic. In the latest Miocene and earliest Pliocene, there were close connections with central Africa, but also remarkable similarities with East Africa, in some instances reaching the species level. There is no evidence of northern influence among large mammals, although several small mammals had a wide range in the Mediterranean. East African or pan-African forms are also largely predominant in the well sampled Late Pliocene, their low diversity resulting probably from local environmental conditions. There are but a few immigrants from Eurasia, mostly carnivores. During the Early Pleistocene, limited exchanges occur with the Middle East, but many more with the rest of Africa. By the Middle Pleistocene similarities with East Africa reach their climax, and it is only with the latest part of this period that some northern immigrants put a Palaearctic stamp on this fauna, the "Ethiopian" character of which decreases by extinction of many of its elements.
\end{abstract}

Keywords - North Africa - Pliocene - Pleistocene - Mammalia - biogeography

\title{
1. Introduction
}

The present-day Sahara, the largest dry desert in the World, is the main geographic feature of Africa, establishing between areas at higher and lower attitudes a biogeographic barrier far more efficient than, e.g., the East African rift. It separates a southern, so-called Ethiopian faunal realm from the Palaearctic one, which incorporates the areas south of the Mediterranean. I believe that looking at such a formidable barrier today has influenced many conceptions about the past biogeographic relationships of North African mammals. In spite of the abundant evidence showing that, as recently as the Holocene, the Sahara was wet and inhabited by a variety of large mammals, the groundless idea that there must have been a proto- 
Sahara barrier perhaps as early as the Miocene has long been admitted (Thomas, 1979; Thomas et al., 1982). However, no detailed comparison of North-African mammalian faunas with European and Ethiopian ones, supporting a North-South distinction, has ever been undertaken. It is likely that the fact that late Cainozoic North African mammalian faunas were mostly studied by French palaeontologists (the first of whom being Camille Arambourg), more acquainted with European faunas than with East African ones, and more prone to compare the North African ones with the ones they knew best, contributed to increase their apparent Palaearctic aspect.

I shall review below the Late Miocene to Late Pleistocene mammalian faunas of Northwestern Africa, roughly in chronological order. There is virtually no absolute dating for the sites of this area, and all ages are estimated by biochronology but, except for some uncertainties mentioned below, these estimates are rather satisfactory.

\section{2. - Biogeographic affinities of mammalian faunas}

\section{1 - Late Miocene and Early Pliocene}

This period is poorly documented in North Africa. The main site is Sahabi in Libya, referred by Bernor and Pavlakis (1987) to the Early Pliocene, but now usually referred to the Late Miocene (Howell, 1987; Geraads, 1989), although probably encompassing more than a short time slice. Its African affinities are numerous (Geraads, 1989), with for instance Redunca, Damalacra, Stegotetrabelodon, and Brachypotherium, all unknown outside this continent at that time. An antelope assigned to a Eurasian genus (Prostrepsiceros for Lehmann and Thomas, 1987, Dytikodorcas for Bouvrain and Bonis, 2007) could well be close instead to the African impala (Aepyceros), thus removing one of the very few northern affinities of the fauna. The Sahabi boselaphine, Tragoportax cyrenaicus, could be closer to the Lothagam one in Kenya (Harris, 2003) than to European forms. Sahabi shares some specific similarities with the fauna of Toros Menalla, in the Late Miocene of Chad. It has an anthracothere (Lihoreau et al., 2006), probably the same species of Machairodus (Peigné et al., 2005), and a primitive hippotragine, Tchadotragus (Geraads et al., 2008). This speaks in favour of a Chado-Libyan sub-province within a larger African one, because hipppotragines are unknown outside Africa at that time, and anthracotheres went extinct in Europe much earlier. This is confirmed by the discovery of late Miocene paleo-rivers flowing north into the Mediterranean from paleo-lake Chad (Griffin, 2006), thus providing easy connection for a variety of mammals.

In the Maghreb, no fauna comparable in richness to that of Sahabi is known. Douaria in Tunisia, the age of which is imprecise but certainly in the 5-8 Ma range, yielded an anthracothere (Pickford, 1991) and two species of rhinos, one of which (Guérin, 1966, and pers. obs.) is close 
to brachypotheres, a group which also went extinct in Europe much earlier. In East Africa instead, it survives until the Late Miocene at Lothagam (Harris and Leakey, 2003), and the fauna of Douaria is thus clearly of African character, showing no definite northern influence.

Such northern forms are also absent from the later site of Hamada Damous, in the same country, which yield a suid intermediate between Nyanzachoerus and Notochoerus (Coppens, 1971); both genera are best known in Early and Middle Pliocene East African sites, but unknown in Europe.

Further West, at Lissasfa in Morocco, close to the Miocene-Pliocene boundary, we (Raynal et al., 1999) discovered a bovine skull close to Ugandax from Central and Eastern Africa, and a canid with upper molars large relative to the carnassial, thus quite distinct from the contemporaneous Spanish form, Canis cipio (Pons-Moyá et al., 1978).

Lissasfa yielded an interesting rich fauna of rodents (Geraads, 1998b) which allowed its precise dating, but also show that they do not follow the same biogeographic pattern as large mammals. We will see that this difference is a steady feature for the whole late Cainozoic. Lissasfa yielded one of the earliest Mus of the western part of the Old World, probably originating from the Siwalik Mus, but this microfauna also includes several taxa that are also present in Western Europe, especially in Spain, or elsewhere in the Mediterranean basin, but are wholly unknown in East or South Africa at that time. These are Paraethomys, Ruscinomys, Myocricetodon, and Protatera. Myocricetodon had a much larger range earlier in the Miocene, but the other three genera were definitely involved in a latitudinal dispersal phase in the latest Miocene. Several other rodents, absent from Lissasfa but present in other North African localities, Apodemus, Castillomys, Eliomys, and Stephanomys (Coiffait-Martin, 1991) confirm the existence of rodent exchanges between North-western Africa and Spain (Geraads, 1998a).

Remarkably, very few large mammals were involved in these exchanges. The earliest North African records of the Cercopithecinae Macaca are at Sahabi and at Menacer, a Turolian site in Algeria (Thomas and Petter, 1986); Delson (1975) surmised that it could be the vicariant sister-taxon of the Papionini, known further south, but this genus has also been reported from the earliest Pliocene of the Middle Awash in Ethiopia. Its occurrence in the latest Miocene of Casablanca-M in Spain (Fortelius, 2007) shows that it certainly crossed the Gibraltar straits. Hippos followed the same route, as they probably originated in Africa from a form close to the Middle and Late Miocene Kenyapotamus (Pickford, 1983), and are present in Spain by the Late Miocene (Venta del Moro, El Arquillo). Camelus (or Paracamelus) is also sometimes cited as an example of trans-Gibraltar connection, but its fossil record in the western part of the Old World is far too incomplete to reconstruct its history. It suddenly appears as early as the latest Miocene 
in Spain (Morales et al., 1980), so that whatever route it followed left no track, which is not surprising, as this group is always quite rare in any site. Subsequent records in the Early Pliocene of Chad (Likius et al., 2003), and Middle Pliocene of North Africa (Arambourg, 1979), could well be the result of a more southern east-west migration. A seemingly Palaearctic element in Pliocene North African faunas is the Caprini of Aïn Brimba in Tunisia (Arambourg, 1979). Caprini have a very sparse record in Africa, but it should be noted that the modern Barbary "sheep", Ammotragus, has been shown to be more distant from goats than previously thought, so that this group could have a long history in Africa (but see below).

\section{2 - Late Pliocene}

Ahl al Oughlam, a fissure filling near Casablanca, is by far the richest site of this period in North Africa, and one of the richest in the Old World, with over 100 vertebrate species, of which 58 are mammals (Geraads, 2006, and refs therein). The large mammals can be divided into 4 groups, according to their biogeographic affinities.

1) Those which already had a very wide distribution before the Late Pliocene, so that it is hard to say if they originate from African forms, or immigrated from elsewhere. Uncertainties may be increased by doubts about the monophyly of some of these genera, which are: Elephas, Anancus, Hystrix, and several carnivores: Hyaenictitherium, Chasmaporthetes, Dinofelis, Felis,

\section{Homotherium.}

2) Those which are certainly of African origin, as they are known in this continent before the time of Ahl al Oughlam, while they are unknown elsewhere. These include a number of carnivores (Geraads, 1997; see also Hendey, 1974; Petter and Howell, 1977; Barry, 1987; Petter, 1987 for the other localities): Herpestes, Ichneumia and Genetta (known as early as the Late Miocene), Civettictis (known from Omo as Viverra leakeyi), Crocuta, Panthera, Acinonyx (all known at Laetoli), Vulpes (known from the Late Miocene of Chad: Bonis et al., 2007), Prepoecilogale (known at Laetoli), Mellivora (known in the Early Pliocene of Langebaanweg in South Africa) and probably Ictonyx (Poecilictis), unknown in the Pliocene, but with no extraAfrican record. Other definitely African forms are: Theropithecus (mostly represented earlier by Th. darti both in East and South Africa: Alemseged and Geraads, 1998), Lepus (reported from Kanapoi: Harris et al., 2003), Hipparion pomeli (which belongs to the H. hasumense group, known at Hadar: Eisenmann and Geraads, 2007), Kolpochoerus (with no Pliocene extra-African record), Sivatherium (definitely known at Langebaanweg), and several bovids (Geraads and Amani, 1997): Tragelaphus and Kobus (two African genera first documented at Langebaanweg), and Beatragus (unknown outside Africa). The North African Late Miocene and Early Pliocene 
record is too patchy to rule out the hypothesis that some of these taxa had a North African origin, but it is likely that most of them arose instead in East or South Africa, later to expand northwards across the present-day Sahara. Non-mammalian Ahl al Oughlam taxa with East African close relatives are the viper Bitis (Bailón, 2000), and the love-birds Agapornis, a genus known only in Africa (C. Mourer-Chauviré, pers. comm.).

3) Those, mostly carnivores, which are probably of northern (European) origin. They include Pliocrocuta, a widespread taxon in Eurasia, but with no record in Africa besides Ahl al Oughlam, Lynx, doubtfully present at Ahl al Oughlam, and known at Çalta and Perpignan (Ginsburg, 1998, but the systematics of this genus is debated: Morales et al., 2003), Nyctereutes, a mainly Eurasian genus, known since the Early Pliocene in Europe before its first (uncertain) record in Africa at Laetoli (Barry, 1987), and Ursus, well known in Europe (Werdelin and Lewis, 2005, mentioned also an ursine bear from East Africa, but this report is so unexpected that it has to be confirmed). The latter taxon provides the best evidence of crossing of the Gibraltar straits, certainly easy for such a good swimmer. Nyctereutes could have followed the same route, as the species from Ahl al Oughlam bears special resemblance to Spanish forms. Pliocrocuta could be of Asiatic origin, but systematics of this group is still imperfectly understood. African otters display a clear disjunction in two groups: all North African ones belong to Lutra, a Eurasian genus unknown at that time south of the present-day Sahara, where it is replaced by Aonyx and Enhydriodon, two genera absent from North Africa; needless to say that Lutra is also a good swimmer.

4) Those whose origin is still debatable. There is a medium size canid whose affinities with Canis and "Eucyon" have not yet been fully worked out. Leporids other than Lepus belong either to Serengetilagus (an East African genus) or to Trischizolagus (a Mediterranean one), while Prolagus is a Mediterranean genus. An alcelaphine antelope, referred to Parmularius, a purely African genus, by Geraads and Amani (1998) might belong instead to Damalops, a genus also known in the latest Pliocene of the Siwaliks (Pilgrim, 1939) and Tajikistan (Dmitrieva, 1977), but still almost certainly of African origin. The affinities of the Bovini from Ahl al Oughlam are still unclear because no reasonably complete horn-core has been found, but its primitive premolars suggest that they might lie with the "Leptobos" from Eurasia.

In spite of the clear similarities of Ahl al Oughlam with East African faunas, some significant elements of the latter are missing in the Moroccan site. These are first the Hominidae, as there is no evidence whatsoever of human presence at Ahl al Oughlam, all Cercopithecidae other than Theropithecus, Deinotherium, all Suidae except Kolpochoerus, Giraffa, and Aepyceros. Remarkably, most of these taxa, if not all of them, are ecologically linked to at least 
some kind of wood cover. This is in agreement with the high proportion of alcelaphine and antilopine bovids at Ahl al Oughlam, a definite indicator of dry open landscape, so that their absence in Morocco might be due to local ecological conditions.

The list of genera that are present in Europe and Western Asia in the Late Pliocene, but absent from North Africa, is much longer. It includes many carnivores: the viverrids Viverra and Megaviverra, the felid Puma (or Jansofelis), the canid Cuon (to which can be added Vulpes of alopecoides type, with long carnassials), and the mustelids Baranogale, Martes, Mustela, and Meles. There are also some large ungulates, such as the rhino Stephanorhinus, the proboscidean Mammut (= Zygolophodon), Tapirus, and a cercopithecid primate, Paradolichopithecus. But the main differences lie in the composition of the artiodactyl faunas, whose northern representatives unknown in the Maghreb at this time include the wild boar Sus, perhaps a palaeotragine giraffid (Mitilanotherium), the various members of the family Cervidae, with at least four genera, Cervus, Croizetoceros, Eucladoceros and Alces s.l., of which there is not a single tooth or bone in Africa, and several bovids whose systematic position is not always clear, but which are definitely not members of the dominant African tribes (Tragelaphini, Reduncini, Hippotragini and Alcelaphini): Gazellospira, Procamptoceras, Pliotragus, Gallogoral, Hemitragus, Megalovis, Ovis.

To express more objectively the similarities between Ahl al Oughlam and other sites of comparable age, I have computed some indices from their faunal lists of large mammals. There are many such indices, based upon the number of taxa shared by the two faunal lists $(A)$, and the numbers of taxa peculiar to each of them $(B$ and $C)$. I chose Simpson index of similarity, $A /(A+$ $B)$ if $B<C$ or $A /(A+C)$ if $C<B$, and Pickford index of distance, transformed to 1-(Pickford index) for homogeneity, thus becoming $A(A+B+C) /(A+B)(A+C)$. They are less sensitive to unequal sampling than some other commonly used indices. Results, at generic level, are provided in Table 1: they clearly show that it is with East African that the similarities are greater, in spite of the difference in latitude. Compared with European sites, even those of closely similar age, the indices are much smaller. Thus, the difference in faunal composition is quite clear, and so sharp that it cannot merely be explained by differences in ecological conditions.

By contrast, the rodents tell again a very different story (Geraads, 1995). In spite of the great number of rodent teeth that have been collected by screening, only five species have been found, besides the widespread Hystrix. They mainly belong to lineages already present in earlier sites, such as Mus, also known in East Africa and the Siwaliks, but totally absent from Europe, and Paraethomys, a genus now extinct in Europe, but which will continue in North Africa, as an endemic lineage, until the end of the Middle Pleistocene. Gerbillus also appears there, at about 
the same time as at Omo in Ethiopia (Wesselman, 1984), and will also have a long history in the Maghreb. Ahl al Oughlam lacks the diversity of murids found in East African sites of this age, but also fully lacks any arvicolid, the dominant group in Europe at that time. Remarkably, this original composition of North African rodent faunas will remain virtually unchanged until the end of the Pleistocene (Jaeger, 1975). Other small mammals show less endemicity. Asoriculus, also known in Morocco at Irhoud Ocre, is present in Europe, while Suncus has been described from East Africa (Wesselman, 1984).

\section{3 - Early Pleistocene}

Faunas of this period are much less rich than that of Ahl al Oughlam. The stratigraphic succession at Aïn Jourdel in Algeria (Thomas, 1884) includes several levels, the lowest being probably of Late Pliocene age, with a new alcelaphine, likely of East African origin, Oreonagor, and an upper level with Tragelaphus gaudryi, a species well-known at Omo (Gentry, 1985) in Ethiopia. Aïn Boucherit has one more alcelaphine genus, certainly immigrated from East Africa, Parmularius (described as Redunca eulmensis by Arambourg, 1979), together with a more derived species of Oreonagor. Parantidorcas is certainly an antilopine, but its affinities remain unclear; it could be related to African Antidorcas, although the strong homonymous torsion of its horn-cores reminds of the Late Miocene Eurasian Oioceros. In any case, there are thus at least two more East African immigrant bovids near the Plio-Pleistocene boundary. However, the best evidence for connections between equatorial Africa and the Maghreb at that time is the arrival of hippos of modern type (tetraprotodont Hippopotamus). They are recorded only slightly later, at perhaps 1.4 Ma, in Western Europe (Atapuerca faunal unit 1: Cuenca-Bescós and García, 2007), where they probably arrived from the East, as they are known in the Early Pleistocene of Ubeidiya in Israel (Faure, 1986) and at Kapetanios in Greece (Koufos and Kostopoulos, 1997). Indices of similarity (Table 2) are again much greater when compared with East Africa than with Eurasia.

The site of Aïn Hanech, stratigraphically above that of Aïn Boucherit, yielded a fauna ecologically similar to that of the latter level, but rather sharply distinct in its faunal composition, suggesting that they are separated by a significant amount of time, and the fauna of Aïn Hanech, probably the earliest North African site documenting human presence, points to an age of perhaps 1.2 to 1.4 Ma. (Geraads et al., 2004, contra Sahnouni et al., 2002). It attests the first immigration of a large canid, considered as closed to Lycaon by Martínez-Navarro and Rook (2003) but lacking the derived features of this genus, and probably closer to Canis atrox from South Africa, to which it was first referred by Arambourg (1979). Other definite immigrants 
from the south are Oryx, also known in the roughly contemporaneous site of Mansourah (ChaidSaoudi et al., 2006) and the large alcelaphine Numidocapra, of which Aïn Hanech is the typelocality of the type-species, but which is also present in Djibouti (Bonis et al., 1988) and the Middle Awash (Vrba, 1997).

There are, however, some possible connections with Eurasia, and especially with the Near East. The bovine described under two different names, Bos bubaloides and B. praeafricanus, by Arambourg (1979) is probably closer to Eurasian Leptobos than to African Pelorovis, in spite of a similar course of its horn-cores. In any case, Pelorovis is also present at Ubeidiya (Geraads, 1986). A very poorly known giraffid, described as Giraffa pomeli by Arambourg but definitely not of this genus, might be close to the Giraffa sp. of Ubeidiya but certainly distinct from East African forms. Giraffids are extinct in Europe at that time. North African representatives of the suid Kolpochoerus seem to belong to a local lineage (Kolpochoerus maroccanus), distinct from the East African ones (Geraads, 2004), but its possible connection with the poorly documented Ubeidiya form remains conjectural. The asinian equid Equus tabeti has been described from both Aïn Hanech (Arambourg, 1970) and Ubeidiya (Eisenmann, 1986).

However, these similarities should not be overestimated, as the Aïn Boucherit and Aïn Hanech faunas remain very different from the Dmanisi (Lordkipanidze et al., 2007) and Ubeidiya ones, which are almost fully Eurasian in character, with especially an overwhelming majority of cervids among ruminants. Indices of similarity (Table 3) show that these latter sites are still much less similar to Aïn Hanech than are the East African ones.

\section{4 - Middle Pleistocene}

The site of Tighenif (= Ternifine) is still the earliest with fossil hominid remains in North Africa, dated to close to the Early / Middle Pleistocene boundary (Geraads et al., 1985). Ecologically, the fauna reminds of those of the earlier sites, with a majority of dry open country forms, oryx, gazelles and Alcelaphini. Most of its genera are also found in East and South Africa, the most characteristic ones being: Lycaon, Theropithecus, Ceratotherium, Loxodonta, Metridiochoerus, and most bovids (Tragelaphus, Oryx, Hippotragus, Parmularius, Connochaetes: Geraads, 1981), although its bovine could be a descendant of the one found at Aïn Hanech, perhaps more closely related to European Leptobos than to the African Pelorovis, and its dominant gazelle, G. dracula, could be related to the earlier European G. borbonica (Gentry, 1990). Trans-African connections far outweigh this only possible evidence of migration from the north, and Tighenif is perhaps the most "East African" of all sites in the Maghreb: the 
first Eurasian site in Table 4, Ubeidiya, has a far lower similarity index with Tighenif than many East African sites.

Rodents (Jaeger, 1975; Geraads et al., 1986) mostly include North African endemic lineages (Paraethomys, gerbillids) plus an East African murid (Arvicanthis) and the only arvicolid of North Africa, Ellobius, definitely of Central Asiatic origin.

Aïn Maarouf near El Hajeb in Morocco yielded a small fauna (Geraads and Amani, 1997) similar to that of Tighenif, but with the addition of a new alcelaphine, Rabaticeras, also reported from a few earlier East and South African sites, testifying to a new immigration from the South.

Recent excavations in the former "Thomas Quarries" near Casablanca allowed refining of the stratigraphy and biochronology of the various archaeological levels in these quarries, now referred to as "Thomas Quarry" (= former Thomas Quarry 1), and "Oulad Hamida 1", (= former Thomas Quarry 3), the latter including mainly the "Grotte des Rhinocéros" (Raynal et al., 1993; Rhodes et al., 2006). Although definitely of various ages, all these levels are younger than Tighenif, from which they can be distinguished by a significant, but not major, turnover: Metridiochoerus is replaced by Phacochoerus, the origin of which is certainly to be sought close to the East African M. hopwoodi, while Kolpochoerus survives; the most common alcelaphine looks close to a strange form from the Okote member of Koobi Fora, referred to ? Damaliscus by Harris (1991). The strongest evidence of a European immigration is a lynx (Geraads, 1980) which might share a relatively recent common ancestry with the modern Spanish Lynx pardina. Despite recent claims to the contrary (Martínez-Navarro et al., 2007) I do not believe that the origin of Bos is to be sought in Africa, the Middle Pleistocene East African Bos (Geraads et al., 2004) being probably of Asiatic origin, while North African late Middle Pleistocene Bos primigenius probably came from Eurasia.

Among rodents, Eliomys re-appears for the first time since the earliest Pliocene, but its similarities with the garden dormouse of the Balearic Islands suggest a new immigration.

\section{5 - Late Pleistocene}

Several new taxa appear during this period, but the documentation during the latter part of the Middle Pleistocene is relatively poor, and they might in fact have arrived earlier. Among bovids, the giant buffalo Pelorovis (or Syncerus) antiquus, and the hartebeest Alcelaphus definitely came from East Africa, where they are known much earlier (Gentry and Gentry, 1978; Vrba, 1997). Ammotragus could be the end product of a North African caprine lineage, or alternatively could be of European origin, as the genus has recently been reported from Le Vallonnet, a ca. 1 Ma site in Southern France (Moullé et al., 2004). Two deer, a small variety of 
the red deer Cervus elaphus, and a megacerine, Megaceroides algericus, also appear during this period, although the precise date of their arrival is unknown. Deer are good swimmers, and the Gibraltar straits, only about $15 \mathrm{~km}$ wide at its narrowest stage, was certainly not impassable, neither for them, nor for Sus, which has been reported from the late Middle Pleistocene (Michel, 1989), and persists until the present-day. This crossing is much less likely for the rhino Stephanorhinus, certainly present during the first half of the Late Pleistocene, and its occurrence at Haua Fteah (Klein and Scott, 1986) in Eastern Libya suggests that it came from the east, following the southern Mediterranean shore. These new immigrants increase the Palaearctic component in North-western African faunas, while the "Ethiopian" component decreases because of the extinction of several of its elements in the course of the Late Pleistocene: Tragelaphini, Hippotragus, Reduncini, Camelus (later re-introduced as a domestic form), Phacochoerus, hippos, Ceratotherium, all disappear before historic times. So, although there is no definite new evidence of immigration from the south during this period, it might well be that this faunal turnover was more related to climatic change in the area itself than to the establishment of the Sahara barrier, the loss of diversity experienced by both the large and small mammals being a clear indicator of environmental stress.

\section{3. - Conclusion}

From the Late Miocene to the Middle Pleistocene, many new lineages of large mammals arose throughout Africa, but most of the centers of origins were probably located in the eastern part of the continent. Then, they expanded their ranges within Africa, as far as no geographical or ecological barrier stopped them. The regular immigration of these new taxa of southern origin in the north-western part of the continent demonstrates that no such efficient barrier can have existed for any long period. This does not mean that there was no desert in the Sahara area: indeed, recent finds have demonstrated the occurrence of desertification as early as the Miocene (Schuster et al., 2006) but the mammalian evidence demonstrates that these desert zones were either not large or not permanent enough to set a barrier preventing migration across it. Our present-day conception of the Sahara is clearly not applicable to this period.

Surprisingly, the human fossil evidence in North-western Africa does not seem to conform to this biogeographic history based upon regular latitudinal exchanges. The complete absence of Hominids at Ahl al Oughlam is most unexpected, given the strong East African aspect of the fauna of this site, which is so rich that this can probably be taken as an evidence of absence of hominids in North Africa at that time. As noted above, other eastern African taxa that are lacking at Ahl al Oughlam are those that require some amount of tree cover, and this suggests 
that the dominant physiognomy of the landscape in North-western Africa in the late Pliocene / early Pleistocene was very open. By contrast, the abundance of cervids in early Eurasian hominid-bearing sites such as Dmanisi or Ubeidiyeh testifies to the preference of early Homo for some wood cover, and their immediate ancestors by the time of Ahl al Oughlam may have had similar requirements, although the presence of Australopithecus in Chad in sites wholly lacking woodland bovids (Geraads et al., 2001) precludes any simple interpretation.

Based upon present knowledge, it is only in the middle part of the Early Pleistocene that hominids appear in North Africa, at Aïn Hanech and Mansourah but, since the environment of these sites was not significantly more wooded than that of Ahl al Oughlam, this can perhaps be seen as an evidence of their increasing adaptability. Later, North African Homo mauritanicus may have followed his own local evolution, without any further connection with African and Eurasian members of the genus. Obviously, environmental conditions were no longer the main determinant of the geographic distribution of these hominids.

\section{Acknowledgments}

I thank J.-P. Brugal and M. R. Palombo for having invited me to contribute this article, which is largely based upon the results of the excavations in Morocco, undertaken in the frame of the "Programme Casablanca", of the INSAP, Rabat, co-directed by F.-Z. Sbihi-Alaoui and J.P. Raynal. I also thank A. Prieur (Université de Lyon), C. Sagne and C. Argot (Muséum National d'Histoire Naturelle, Paris), M. Boutakiout (Université de Rabat), for access to collections,

A. Guillaumont for help with computing indices, and two anonymous reviewers who suggested useful improvements.

\section{References}

Alemseged, Z., Geraads, D. 1998. Theropithecus atlanticus (Thomas, 1884) (Primates:

Cercopithecidae) from the late Pliocene of Ahl al Oughlam, Casablanca, Morocco. Journal of Human Evolution 34 (6), 609-621.

Arambourg, C. 1979. Vertébrés villafranchiens d'Afrique du Nord - Carnivores, Artiodactyles, Primates. Fondation Singer-Polignac, Paris, pp. 1-141.

Bailón, S. 2000. Amphibiens et reptiles du Pliocène terminal d'Ahl al Oughlam (Casablanca, Maroc). Geodiversitas 22 (4), 539-558.

Barry, J. C. 1987. Large carnivores (Canidae, Hyaenidae, Felidae) from Laetoli. In: Leakey, M. D., Harris, J. M. (Eds), Laetoli, a Pliocene site in Northern Tanzania. Clarendon Press, Oxford, pp. 235-258. 
Bernor, R. L., Pavlakis, P. P. 1987. Zoogeographic Relationships of the Sahabi Large Mammal Fauna (Early Pliocene, Libya). In: Boaz, N. T., El, Arnauti A., Gaziry, A. W., Heinzelin, J. de, Boaz, D. D. (Eds), Neogene Palaeontology and Geology of Sahabi. A. Liss, New York, pp. 349-383.

Bonis, L. de, Geraads, D., Jaeger, J. J., Sen, S. 1988. Vertébrés du Pléistocène de Djibouti. Bulletin de la Société Géologique de France 4 (2), 323-334.

Bonis, L. de, Peigné, S., Likius, A., Mackaye, H. T., Vignaud, P., Brunet, M. 2007. The oldest African fox (Vulpes riffautae n.sp., Canidae, Carnivora) recovered in late Miocene deposits of the Djurab desert, Chad. Naturwissenschaften 94, 575-580.

Bouvrain, G., Bonis, L. de, 2007. Ruminants (Mammalia, Artiodactyla: Tragulidae, Cervidae, Bovidae) des gisements du Miocène supérieur (Turolien) de Dytiko (Grèce). Annales de Paléontologie 93, 121-147.

Chaid-Saoudi, Y., Geraads, D., Raynal, J.-P. 2006. The fauna and associated artefacts from the lower Pleistocene site of Mansourah (Constantine, Algeria). Comptes-rendus Palevol 5, 963-971.

Coiffait-Martin, B. 1991. Contribution des Rongeurs du Néogène d'Algérie à la biochronologie mammalienne d'Afrique Nord-occidentale. Thèse Univ. Nancy, 389 p. (unpubl.)

Coppens, Y. 1971. Une nouvelle espèce de Suidé du Villafranchien de Tunisie, Nyanzachoerus jaegeri nov. sp. Comptes rendus de l'Académie des Sciences 272, 3264-3267.

Cuenca-Bescós, G., García, N. 2007. Biostratigraphic succession of the Early and Middle Pleistocene mammal faunas of the Atapuerca cave sites (Burgos, Spain). Courier Forschungs-Institut Senckenberg 259, 79-92.

Delson, E. 1975. Evolutionary History of the Cercopithecidae. In: Szalay, F. (Ed.). Approaches to Primate Paleobiology. Contributions to Primatology 5, pp. 167-217.

Dmitrieva, E.L. 1977. Neogene Antelopes of Mongolia and adjacent territories. The joint SovietMongolian Paleontological Expedition. 6. Akademia Nauk SSSR, pp. 5-119 (in Russian). Eisenmann, V. 1986. Les Equidés d'Oubeidiyeh. In : Tchernov, E. (Ed.), Les Mammifères du Pléistocène inférieur de la vallée du Jourdain à Oubeidiyeh. Mémoires et Travaux du centre de Recherches Français de Jérusalem 5, 191-212.

Eisenmann, V., Geraads, D. 2007. The hipparion from the late Pliocene of Ahl al Oughlam, Morocco, and a revision of the relationships of Pliocene and Pleistocene African hipparions. Paleontologia Africana 42, 51-98.

Faure, M. 1986. Les Hippopotamidés du Pléistocène ancien d'Oubeidiyeh (Israël). In : Tchernov, E. (Ed.), Les Mammifères du Pléistocène inférieur de la vallée du Jourdain à Oubeidiyeh. 
Mémoires et Travaux du centre de Recherches Français de Jérusalem 5, 107-142.

Fortelius, M. (coordinator) 2007. Neogene of the Old World Database of Fossil Mammals (NOW). University of Helsinki. http://www.helsinki.fi/science/now/.

Gentry, A. W. 1985. The Bovidae of the Omo deposits, Ethiopia. In: Coppens, Y., Clark Howell, F. (Eds), Les faunes plio-pleistocènes de la basse vallée de l'Omo (Ethiopie). Cahiers de Paléontologie-Travaux de paléontologie est-africaine, CNRS, pp. 119-191.

Gentry, A. W. 1990. Evolution and Dispersal of African Bovidae. In: Bubenik, G. A., Bubenik, A. B. (Eds.), Horns, Pronghorns, and Antlers. Evolution, Morphology, Physiology, and Social Significance. Springer, New York, pp. 195-227.

Gentry, A. W., Gentry, A. 1978. Fossil Bovidae (Mammalia) of Olduvai Gorge, Tanzania. Part I. Bulletin of the British Museum (Natural History)- Geology 29 (4), 289-446.

Geraads, D. 1980. Un nouveau félidé (Fissipeda, Mammalia) du Pléistocène du Maroc : Lynx thomasi n.sp. Geobios 13 (3), 441-444.

Geraads, D. 1981. Bovidae et Giraffidae (Artiodactyla, Mammalia) du Pléistocène de Ternifine (Algérie). Bulletin du Muséum national d'Histoire naturelle 3 (1), 47-86.

Geraads, D.1986. Ruminants pléistocènes d'Oubeidiyeh (Israël). In : Tchernov, E. (Ed.), Les Mammifères du Pléistocène inférieur de la vallée du Jourdain à Oubeidiyeh. Mémoires et Travaux du centre de Recherches Français de Jérusalem 5, 143-181.

Geraads, D. 1989. Vertébrés fossiles du Miocène supérieur du Djebel Krechem El Artsouma (Tunisie centrale). Comparaisons biostratigraphiques. Geobios 22 (6), 777-801.

Geraads, D. 1995. Rongeurs et insectivores (Mammalia) du Pliocène final de Ahl al Oughlam (Casablanca, Maroc). Geobios 28 (1), 99-115.

Geraads, D. 1997. Carnivores du Pliocène terminal de Ahl al Oughlam (Casablanca, Maroc). Geobios 30 (1), 127-164.

Geraads, D. 1998a. Biogeography of circum-Mediterranean Miocene Pliocene rodents; a revision using factor analysis and parsimony analysis of endemicity. Palaeogeography, Palaeoclimatology, Palaeoecology 137, 273-288.

Geraads, D. 1998b. Rongeurs du Mio-Pliocène de Lissasfa (Casablanca, Maroc). Geobios 31 (2), 229-245.

Geraads, D. 2004. New skulls of Kolpochoerus phacochoeroides (Suidae: Mammalia) from the late Pliocene of Ahl al Oughlam, Morocco. Palaeontologia africana 40, 69-83.

Geraads, D. 2006. The late Pliocene locality of Ahl al Oughlam, Morocco: vertebrate fauna and interpretation. Transactions of the Royal Society of South Africa 61 (2), 97-101.

Geraads, D., Alemseged, Z., Reed, D., Wynn, J., Roman, D. C. 2004. The Pleistocene fauna 
(other than Primates) from Asbole, lower Awash Valley, Ethiopia, and its environmental and biochronological implications. Geobios 37 (6), 697-718.

Geraads, D., Amani, F. 1997. La faune du gisement à Homo erectus de l'Aïn Maarouf, près de El Hajeb (Maroc). Anthropologie 101 (3), 522-530.

Geraads, D., Amani, F. 1998. Bovidae (Mammalia) du Pliocène final d'Ahl al Oughlam, Casablanca, Maroc. Paläontologische Zeitschrift 72 (1-2), 191-205.

Geraads, D., Blondel, C., Likius, A., Mackaye, H. T., Vignaud, P., Brunet, M. 2008. New Hippotragini (Bovidae) from the late Miocene of Toros-Menalla, Chad. Journal of Vertebrate Palaeontology 28(1), 231-242.

Geraads, D., Brunet, M., Mackaye, H. T., Vignaud, P. 2001. Pliocene Bovidae (Mammalia) from the Koro-Toro Australopithecine sites, Chad. Journal of Vertebrate Palaeontology 21(2), 325-346.

Geraads, D., Hublin, J. J., Jaeger, J. J., Sen, S., Tong, H., Toubeau, P. 1986. The pleistocene Hominid site of Ternifine, Algeria: new results on the environment, age, and human industries. Quaternary Research 225, 380-386.

Geraads, D., Raynal, J.-P., Eisenmann, V. 2004. The earliest human occupation of North Africa: a reply to Sahnouni et al. (2002). Journal of Human Evolution 46, 751-761.

Ginsburg, L. 1998. Le gisement de vertébrés pliocènes de Çalta, Ankara, Turquie.5. Carnivores. Geodiversitas 20 (3), 379-396.

Griffin, D. L. 2006. The late Neogene Sahabi rivers of the Sahara and their climatic and environmental implications for the Chad basin. Journal of the Geological Society, London 163, 905-921.

Guérin, C. 1966. Diceros douariensis nov. sp., un Rhinocéros du Mio-Pliocène de Tunisie du Nord. Documents des Laboratoires de Géologie de la Faculté des Sciences de Lyon 16, 150 .

Harris, J. M., 1991. Family Bovidae. In: Harris, J. M. (Ed.), Koobi Fora Research Project.

Volume 3 : The fossil ungulates : Geology, Fossil artiodactyls and palaeoenvironments, 3, Clarendon Press, Oxford, pp. 139-320.

Harris, J. M., 2003. Bovidae from the Lothagam succession. In: Leakey, M. G., Harris, J. M. (Eds.), Lothagam - The dawn of humanity in Eastern Africa, Columbia University Press, New York, pp. 531-582.

Harris, J. M., Leakey, M. G., 2003. Lothagam Rhinocerotidae. In: Leakey, M. G., Harris, J. M. (Eds.), Lothagam - The dawn of humanity in Eastern Africa, Columbia University Press, New York, pp. 371-386. 
Harris, J. M., Leakey, M. G., Cerling T. E., 2003. Early Pliocene Tetrapod Remains from Kanapoi, Lake Turkana Basin, Kenya. In: J. M. Harris, M. G. Leakey (Eds.), Geology and Vertebrate Paleontology of the Early Pliocene site of Kanapoi, Northern Kenya. Contribution in science, Natural history Museum of Los Angeles County 498, pp. 39-114. Hendey, Q. B. 1974. The late Cenozoic Carnivora of the South-Western Cape Province. Annals of the South African Museum 63, 1-369.

Howell, F. C. 1987. Preliminary observations on Carnivora from the Sahabi formation (Libya). In: Boaz, N. T., El, Arnauti A., Gaziry, A. W., Heinzelin, J. de, Boaz, D. D. (Eds), Neogene Palaeontology and Geology of Sahabi. A. Liss, New York, pp. 153-181. Jaeger, J.-J. 1975. Les Muridae (Mammalia, Rodentia) du Pliocène et du Pléistocène du Maghreb. Origine; Evolution; Données biogéographiques et paléoclimatiques. Thesis USTL, Montpellier (unpubl.), pp. 1-216.

Klein, R. G., Scott, K. 1986. Re-analysis of Faunal Assemblages from the Haua Fteah and other Late Quaternary Archaeological Sites in Cyrenaican Libya. Journal of Archaeological Science 13, 515-542.

Koufos, G. D., Kostopoulos, D. S. 1997. Biochronology and succession of the Plio-Pleistocene macromammalian localities of Greece. Mémoires et Travaux de l'E.P.H.E., Institut de Montpellier 21, 619-634.

Lehmann, U., Thomas, H. 1987. Fossil Bovidae (Mammalia) from the Mio-Pliocene of Sahabi, Libya. In: Boaz, N. T., El, Arnauti A., Gaziry, A. W., Heinzelin, J. de, Boaz, D. D. (Eds), Neogene Palaeontology and Geology of Sahabi. A. Liss, New York, pp. 323-335.

Lihoreau, F., Boisserie, J. R., Viriot, L., Coppens, Y., Likius, A., Mackaye, H. T., Tafforeau, P., Vignaud, P., Brunet, M. 2006. Anthracothere dental anatomy reveals a late Miocene Chado-Libyan bioprovince. Proceedings of the National Academy of Sciences 103 (23), 8763-8767.

Likius, A., Brunet, M., Geraads, D., Vignaud, P. 2003. Le plus vieux Camelidae (Mammalia, Artiodactyla) d'Afrique : limite Mio-Pliocène, Tchad. Bulletin de la Société Géologique de France 174 (2), 187-193.

Lordkipanidze, D., Jashashvili, T., Vekua, A., Ponce de León, M.S., Zollikofer, C. P. E., Rightmire, G. P., Pontzer, H., Ferring, R., Oms, O., Tappen, M., Bukhsianidze, M., Agusti, J., Kahlke, R., Kiladze, G., Martínez-Navarro, B., Mouskhelishvili, A., Nioradze, M., Rook, L. 2007. Postcranial evidence from early Homo from Dmanisi, Georgia. Nature 449, 305-310.

Martínez-Navarro, B., Rook, L. 2003. Gradual evolution in the African hunting dog lineage: 
systematic implications. Comptes-rendus Palevol 2, 695-702.

Martínez-Navarro, B., Pérez-Claros, J., Palombo, M. R., Rook, L., Palmqvist, P. 2007. The Olduvai buffalo Pelorovis and the origin of Bos. Quaternary research 68, 220-226.

Michel, P. 1989. Contribution à l'étude paléontologique des Vertébrés fossiles du Quaternaire marocain à partir de sites du Maroc atlantique, central et oriental. Thesis, Muséum National d'Histoire Naturelle, Paris, pp. 1-1152.

Morales, J., Soria, D., Aguirre, E. 1980. Camelido finimioceno en Venta del Moro, primera cita para Europa Occidental. Estudios geológicos 36 (1-2), 139-142.

Morales, J., Soria, D., Montoya, P., Pérez, P., Salesa, M. J. 2003. Caracal depereti nov. sp. y Felis aff. silvestris (Felidae, Mammalia) del Plioceno inferior de Layna (Soria, España) . Estudios geológicos 59 (1-4), 229-247.

Moullé, P.-E., Echassoux, A., Martínez-Navarro, B. 2004. Ammotragus europaeus : une nouvelle espèce de Caprini (Bovidae, Mammalia) du Pléistocène inférieur à la grotte du Vallonnet (France). Comptes-rendus Palevol 3, 663-673.

Peigné, S., Bonis, L. de, Likius, A., Mackaye, H. T., Vignaud, P., Brunet, M. 2005. A new machairodontine (Carnivora, Felidae) from the Late Miocene hominid locality of TM 266, Toros-Menalla, Chad. Comptes-rendus Palevol 4 (3), 243-253.

Petter, G. 1987. Small carnivores (Viverridae, Mustelidae, Canidae) from Laetoli. In: Leakey, M. D., Harris, J. M. (Eds.), Laetoli, a Pliocene site in Northern Tanzania. Clarendon Press, Oxford, pp. 194-234.

Petter, G., Howell, F. C. 1977. Diversification des Civettes (Carnivora, Viverridae) dans les gisements pléistocènes de l'Omo. Comptes rendus de l'Académie des Sciences 284 (4), 283-286.

Pickford, M. 1983. On the origins of Hippopotamidae together with decriptions of two new species, a new genus and a new subfamily from the Miocene of Kenya. Geobios 16 (2), 193-217.

Pickford, M. 1991. Revision of the Neogene Anthracotheriidae of Africa. In: Salem, M. J., Hammuda, O. S., Eliagoubi, B. A. (Eds), The Geology of Libya. Elsevier, Amsterdam, pp. 1491-1525.

Pilgrim, G. E. 1939. The Fossil Bovidae of India. Memoirs of the Geological Survey of India 26 (1), 1-356 .

Pons-Moyá, J., Crusafont Pairó, M. 1978. El Canis cipio Crusafont (1950), comparación con los canidos del Plioceno y Pleistoceno europeo. Acta Geológica Hispánica 13 (4), 133-136.

Raynal, J. P., Geraads, D., Magoga, L., El, H. A., Texier J.P., Lefevre, D., Sbihi-Alaoui, F. Z. 
1993. La grotte des Rhinocéros (carrière Oulad Hamida 1, anciennement Thomas III, Casablanca), nouveau site acheuléen du Maroc atlantique. Comptes rendus de l'Académie des Sciences 316, 1477-1483.

Raynal, J. P., Lefèvre, D., Geraads, D., El Graoui, M. 1999. Contribution du site paléontologique de Lissasfa (Casablanca, Maroc) à une nouvelle interprétation du Mio-Pliocène de la Méseta. Comptes-rendus de l'Académie des Sciences, Paris, Sciences de la Terre et des Planètes 329 (8), 617-622.

Rhodes, E. J., Singarayer, J. S., Raynal, J.-P., Westaway, K. E., Sbihi-Alaoui, F. Z. 2006. New age estimates for the Paleolithic assemblages and Pleistocene succession of Casablanca, Morocco. Quaternary Science reviews 25, 2569-2585.

Sahnouni, M., Hadjouis, D., van der Made, J., Derradji, A., Canals, A., Medig, M., Belahrech, H., Harichane, Z., Rabhi, M. 2002. Further research at the Oldowan site of Aïn Hanech, North-eastern Algeria. Journal of Human Evolution 43, 925-937.

Schuster, M., Duringer, P., Ghienne, J.-F., Vignaud, P., Mackaye, H. T., Likius, A., Brunet, M. 2006. The age of the Sahara desert. Science 311, 821.

Thomas, H. 1979. Le rôle de barrière écologique de la ceinture saharo-arabique au Miocène: arguments paléontologiques. Bulletin du Muséum national d'Histoire naturelle C 4(2), 127-135.

Thomas, H., Bernor, R. L., Jaeger, J. J. 1982. Origines du peuplement mammalien en Afrique du Nord durant le Miocène terminal. Geobios 15, 283-297.

Thomas, H., Petter, G. 1986. Révision de la faune de mammifères du Miocène supérieur de Menacer (ex-Marceau), Algérie : discussion sur l'âge du gisement. Geobios 19 (3), 357373.

Thomas, P. 1884. Recherches stratigraphiques et paléontologiques sur quelques formations d'eau douce de l'Algérie. Mémoires de la Société géologique de France 3, 1-51.

Vrba, E. S. 1997. New fossils of Alcelaphini and Caprinae (Bovidae : Mammalia) from Awash, Ethiopia, and phylogenetic analysis of Alcelaphini. Palaeontologia Africana 34, 127-198.

Werdelin, L., Lewis, M. 2005. Plio-Pleistocene Carnivora of eastern Africa: species richness and diversity patterns. Zoological Journal of the Linnean Society 144, 121-144.

Wesselman, H. B. 1984. The Omo micromammals. Contributions to Vertebrate Evolution 7, 1219. 


\section{Figure captions}

Fig. 1. Situation of the localities mentioned in Tables 1-4.

Fig. 2. Range of some North-African mammalian taxa, together with their range (when larger) in the rest of Africa (dotted line) and in Eurasia (dashed line). The main sites are listed at left at their approximate chronological position, but they may not sample all contemporaneous taxa. Chronological scale is logarithmic. 
Table 1. Simpson index of similarity and 1-(Pickford index of distance) of Ahl al Oughlam compared with some North African (AFN), Central African (AFC), East African (AFE), South African (AFS), Western European (EURW), Eastern European (EURE), and Central Asian (ASC) sites of comparable age. Faunal lists have been updated from a variety of sources.

\begin{tabular}{|c|c|c|c|c|c|}
\hline \multicolumn{6}{|c|}{ AHL AL OUGHLAM } \\
\hline \multicolumn{3}{|c|}{ SIMPSON INDEX } & \multicolumn{3}{|c|}{ 1-PICKFORD INDEX } \\
\hline Turkana Late Plioc. & AFE & 0.737 & Turkana Late Plioc. & AFE & 0.825 \\
\hline Turkana Early Pleisto. & AFE & 0.632 & Peninj & AFE & 0.799 \\
\hline Aïn Boucherit & AFN & 0.615 & Ichkeul+Brimba & AFN & 0.789 \\
\hline Ichkeul+Brimba & AFN & 0.6 & Aïn Boucherit & AFN & 0.777 \\
\hline Bouri-Hata & AFE & 0.579 & Hadar-KH & AFE & 0.776 \\
\hline Konso Gardula 12 & AFE & 0.579 & Tighenif & AFN & 0.776 \\
\hline Peninj & AFE & 0.579 & Turkana Early Pleisto. & AFE & 0.754 \\
\hline Hadar-KH & AFE & 0.526 & Bouri-Hata & AFE & 0.744 \\
\hline Tighenif & AFN & 0.526 & Konso Gardula 12 & AFE & 0.744 \\
\hline Chiwondo3A & AFS & 0.474 & Olduvai up. + mid. bed II & AFE & 0.699 \\
\hline Hadar-DD & AFE & 0.474 & Hadar-SH & AFE & 0.689 \\
\hline Hadar-SH & AFE & 0.474 & Hadar-DD & AFE & 0.671 \\
\hline Laetoli upper bed & AFE & 0.474 & Chiwondo3A & AFS & 0.637 \\
\hline Olduvai up. + mid. bed II & AFE & 0.474 & Laetoli upper bed & AFE & 0.637 \\
\hline Aïn Hanech & AFN & 0.462 & Aïn Hanech & AFN & 0.632 \\
\hline Koro-Toro & AFC & 0.429 & Koro-Toro & AFC & 0.609 \\
\hline Olduvai bed I & AFE & 0.368 & Olduvai bed I & AFE & 0.601 \\
\hline Ubeidiya & EURE & 0.333 & Ubeidiya & EURE & 0.544 \\
\hline Makapan 3-4 & AFS & 0.263 & Makapan 3-4 & AFS & 0.417 \\
\hline St Vallier & EURW & 0.214 & Sterkfontein 4 & AFS & 0.368 \\
\hline Sterkfontein 4 & AFS & 0.211 & St Vallier & EURW & 0.338 \\
\hline Atapuerca FU1 & EURW & 0.2 & Atapuerca FU1 & EURW & 0.284 \\
\hline La Puebla & EURW & 0.182 & La Puebla & EURW & 0.268 \\
\hline Almenara & EURW & 0.167 & Kromdraai A & AFS & 0.254 \\
\hline Kromdraai A & AFS & 0.167 & Sesklon & EURE & 0.254 \\
\hline Sesklon & EURE & 0.167 & Kuruksai & ASC & 0.225 \\
\hline Kuruksai & ASC & 0.133 & Almenara & EURW & 0.211 \\
\hline Kopala 2 & ASC & 0.111 & Kopala 2 & ASC & 0.158 \\
\hline Tegelen & EURW & 0.111 & Tegelen & EURW & 0.158 \\
\hline Chilhac & EURW & 0.1 & Gerakarou & EURE & 0.147 \\
\hline Gerakarou & EURE & 0.1 & Podpusk-Lebyazhje & ASC & 0.147 \\
\hline Podpusk-Lebyazhje & ASC & 0.1 & Chilhac & EURW & 0.147 \\
\hline Senèze & EURW & 0.059 & Senèze & EURW & 0.108 \\
\hline Dmanisi & EURE & 0 & Dmanisi & EURE & 0 \\
\hline Livakos & EURE & 0 & Livakos & EURE & 0 \\
\hline Varshets & EURE & 0 & Varshets & EURE & 0 \\
\hline
\end{tabular}


Table 2. Same as for Table 1, but for Aïn Boucherit.

\begin{tabular}{|c|c|c|c|c|c|}
\hline \multicolumn{6}{|c|}{ AIIN BOUCHERIT } \\
\hline \multicolumn{3}{|c|}{ SIMPSON INDEX } & \multicolumn{3}{|c|}{ 1-PICKFORD INDEX } \\
\hline Bouri Daka & AFE & 0.692 & Aïn Hanech & AFN & 0.852 \\
\hline Konso Gardula 12 & AFE & 0.692 & Peninj & AFE & 0.824 \\
\hline Peninj & AFE & 0.692 & Bouri Daka & AFE & 0.808 \\
\hline Turkana Early Pleisto. & AFE & 0.692 & Konso Gardula 12 & AFE & 0.791 \\
\hline Ahl al Oughlam & AFN & 0.615 & Ahl al Oughlam & AFN & 0.777 \\
\hline Aïn Hanech & AFN & 0.615 & Turkana Early Pleisto. & AFE & 0.769 \\
\hline Elandsfontein & AFS & 0.615 & Elandsfontein & AFS & 0.744 \\
\hline Konso Gardula 34 & AFE & 0.615 & Olduvai bed IV & AFE & 0.744 \\
\hline Olduvai bed IV & AFE & 0.615 & MK-GarbalV & AFE & 0.74 \\
\hline Turkana Late Plioc. & AFE & 0.615 & Konso Gardula 34 & AFE & 0.734 \\
\hline MK-Garba IV & AFE & 0.538 & Turkana Late Plioc. & AFE & 0.689 \\
\hline Bouri-Hata & AFE & 0.462 & Ichkeul+Brimba & AFN & 0.677 \\
\hline Ichkeul+Brimba & AFN & 0.462 & Ubeidiya & EURE & 0.641 \\
\hline Tighenif & AFN & 0.462 & Tighenif & AFN & 0.632 \\
\hline Ubeidiya & EURE & 0.462 & Bouri-Hata & AFE & 0.577 \\
\hline Bou Knadel & AFN & 0.385 & Bou Knadel & AFN & 0.556 \\
\hline Hadar-KH & AFE & 0.385 & Hadar-KH & AFE & 0.547 \\
\hline Olduvai up. + mid. bed II & AFE & 0.385 & Sesklon & EURE & 0.538 \\
\hline Kopala 2 & ASC & 0.333 & Olduvai up. + mid. bed II & AFE & 0.531 \\
\hline Livakos & EURE & 0.333 & St Vallier & EURW & 0.505 \\
\hline Sesklon & EURE & 0.333 & Kopala 2 & ASC & 0.487 \\
\hline Makapan 3-4 & AFS & 0.308 & Livakos & EURE & 0.487 \\
\hline Olduvai bed I & AFE & 0.308 & Chilhac & EURW & 0.462 \\
\hline St Vallier & EURW & 0.308 & Gerakarou & EURE & 0.462 \\
\hline Chilhac & EURW & 0.3 & Podpusk-Lebyazhje & ASC & 0.462 \\
\hline Gerakarou & EURE & 0.3 & Olduvai bed I & AFE & 0.453 \\
\hline Podpusk-Lebyazhje & ASC & 0.3 & La Puebla & EURW & 0.441 \\
\hline La Puebla & EURW & 0.273 & Makapan 3-4 & AFS & 0.423 \\
\hline Sterkfontein 4 & AFS & 0.231 & France MNQ20 & EURW & 0.385 \\
\hline France MNQ 20 & EURW & 0.231 & Sterkfontein 4 & AFS & 0.346 \\
\hline Tegelen & EURW & 0.222 & Tegelen & EURW & 0.342 \\
\hline Atapuerca FU1 & EURW & 0.2 & Atapuerca FU1 & EURW & 0.323 \\
\hline Kromdraai A & AFS & 0.167 & Kromdraai A & AFS & 0.295 \\
\hline Varshets & EURE & 0.167 & Dmanisi & EURE & 0.275 \\
\hline Dmanisi & EURE & 0.154 & Senèze & EURW & 0.253 \\
\hline Senèze & EURW & 0.154 & Varshets & EURE & 0.231 \\
\hline
\end{tabular}


Table 3. Same as for Table 1, but for Aïn Hanech.

\begin{tabular}{|c|c|c|c|c|c|}
\hline \multicolumn{6}{|c|}{ AIIN HANECH } \\
\hline \multicolumn{3}{|c|}{ SIMPSON INDEX } & \multicolumn{3}{|c|}{ 1-PICKFORD INDEX } \\
\hline Bouri Daka & AFE & 0.846 & Bouri Daka & AFE & 0.917 \\
\hline Turkana Early Pleisto. & AFE & 0.846 & Turkana Early Pleisto. & AFE & 0.893 \\
\hline Turkana Late Plioc. & AFE & 0.846 & Turkana Late Plioc. & AFE & 0.886 \\
\hline Konso Gardula 12 & AFE & 0.769 & Aïn Boucherit & AFN & 0.852 \\
\hline Elandsfontein & AFS & 0.692 & Konso Gardula 12 & AFE & 0.852 \\
\hline Konso Gardula 34 & AFE & 0.692 & Peninj & AFE & 0.824 \\
\hline Olduvai bed IV & AFE & 0.692 & Elandsfontein & AFS & 0.808 \\
\hline Peninj & AFE & 0.692 & MK-Garba IV & AFE & 0.808 \\
\hline Aïn Boucherit & AFN & 0.615 & Olduvai bed IV & AFE & 0.808 \\
\hline MK-Garba IV & AFE & 0.615 & Konso Gardula 34 & AFE & 0.799 \\
\hline Tighenif & AFN & 0.615 & Ubeidiya & EURE & 0.786 \\
\hline Ubeidiya & EURE & 0.615 & Tighenif & AFN & 0.777 \\
\hline Asbole & AFE & 0.538 & Asbole & AFE & 0.692 \\
\hline Olduvai up. + mid. bed II & AFE & 0.538 & Olduvai up. + mid. bed II & AFE & 0.692 \\
\hline Ahl al Oughlam & AFN & 0.462 & Isenya & AFE & 0.677 \\
\hline Isenya & AFE & 0.462 & Ahl al Oughlam & AFN & 0.632 \\
\hline Mosbach 5 & EURW & 0.4 & Olduvai lower bed II & AFE & 0.59 \\
\hline Bou Knadel & AFN & 0.385 & Mosbach 5 & EURW & 0.585 \\
\hline Olduvai I & AFE & 0.385 & Bou K & AFN & 0.556 \\
\hline Olduvai lower bed II & AFE & 0.385 & Olduvai I & AFE & 0.547 \\
\hline Atapuerca FU4 5 & EURW & 0.333 & France MNQ20 & EURW & 0.492 \\
\hline Kopala 2 & ASC & 0.333 & Atapuerca FU4 5 & EURW & 0.487 \\
\hline Livakos & EURE & 0.333 & Kopala 2 & ASC & 0.487 \\
\hline France MNQ20 & EURW & 0.308 & Livakos & EURE & 0.487 \\
\hline Gerakarou & EURE & 0.3 & Gerakarou & EURE & 0.462 \\
\hline Untermassfeld & EURW & 0.25 & Untermassfeld & EURW & 0.423 \\
\hline Dmanisi & EURE & 0.231 & Dmanisi & EURE & 0.396 \\
\hline Ichkeul+Brimba & AFN & 0.231 & St Vallier & EURW & 0.396 \\
\hline St Vallier & EURW & 0.231 & Ichkeul+Brimba & AFN & 0.385 \\
\hline Sterkfontein 4 & AFS & 0.231 & Sterkfontein 4 & AFS & 0.346 \\
\hline Tegelen & EURW & 0.222 & Tegelen & EURW & 0.342 \\
\hline Atapuerca FU1 & EURW & 0.2 & Atapuerca FU1 & EURW & 0.323 \\
\hline Chilhac & EURW & 0.2 & Chilhac & EURW & 0.323 \\
\hline Varshets & EURE & 0.167 & Senèze & EURW & 0.253 \\
\hline Makapan3-4 & AFS & 0.154 & Varshets & EURE & 0.231 \\
\hline Senèze & EURW & 0.154 & Makapan 3-4 & AFS & 0.224 \\
\hline Apollonia & EURE & 0.143 & Apollonia & EURE & 0.209 \\
\hline
\end{tabular}


Table 4. Same as for Table 1, but for Tighenif.

\begin{tabular}{|c|c|c|c|c|c|}
\hline \multicolumn{6}{|c|}{ TIGHENIF } \\
\hline \multicolumn{3}{|c|}{ SIMPSON INDEX } & \multicolumn{3}{|c|}{ 1-PICKFORD INDEX } \\
\hline Turkana Late Plioc. & AFE & 0.947 & Turkana Late Plioc. & AFE & 0.97 \\
\hline Turkana Early Pleisto. & AFE & 0.842 & Elandsfontein & AFS & 0.921 \\
\hline Elandsfontein & AFS & 0.789 & Turkana Early Pleisto. & AFE & 0.912 \\
\hline Bouri Daka & AFE & 0.684 & Bouri Daka & AFE & 0.855 \\
\hline Konso Gardula 34 & AFE & 0.684 & Konso Gardula 34 & AFE & 0.842 \\
\hline Peninj & AFE & 0.632 & Peninj & AFE & 0.842 \\
\hline MK-GarbalV & AFE & 0.625 & MK-GarbalV & AFE & 0.822 \\
\hline Aïn Hanech & AFN & 0.615 & Aïn Hanech & AFN & 0.777 \\
\hline Olduvai bed IV & AFE & 0.579 & Ahl al Oughlam & AFN & 0.776 \\
\hline Isenya & AFE & 0.533 & Olduvai bed IV & AFE & 0.772 \\
\hline Ahl al Oughlam & AFN & 0.526 & Olduvai up. + mid. bed II & AFE & 0.752 \\
\hline Lainyamok & AFE & 0.526 & Bou Knadel & AFN & 0.737 \\
\hline Olduvai up. + mid. bed II & AFE & 0.526 & Lainyamok & AFE & 0.732 \\
\hline Bou Knadel & AFN & 0.5 & Isenya & AFE & 0.73 \\
\hline Olduvai I & AFE & 0.474 & Old & AFE & 0.723 \\
\hline Aïn Boucherit & AFN & 0.462 & Ubeidiya & EURE & 0.678 \\
\hline Ubeidiya & EURE & 0.444 & Asbole & AFE & 0.642 \\
\hline Asbole & AFE & 0.421 & Aïn Boucherit & AFN & 0.632 \\
\hline Olduvai lower bed II & AFE & 0.4 & Olduvai lower bed II & AFE & 0.589 \\
\hline Atapuerca FU4 5 & EURW & 0.333 & Sterk & AFS & 0.521 \\
\hline Ichkeul+Brimba & AFN & 0.333 & Ichkeul+Brimba & AFN & 0.509 \\
\hline Makapan 3-4 & AFS & 0.316 & Makapan 3-4 & AFS & 0.487 \\
\hline Sterkfontein 4 & AFS & 0.316 & Atapuerca FU4 5 & EURW & 0.439 \\
\hline Atapuerca FU1 & EURW & 0.3 & Atapuerca FU1 & EURW & 0.411 \\
\hline Kromdraai A & AFS & 0.25 & Kromdraai A & AFS & 0.368 \\
\hline Untermassfeld & EURW & 0.25 & Untermassfeld & EURW & 0.368 \\
\hline Kopala 2 & ASC & 0.222 & Kopala 2 & ASC & 0.304 \\
\hline Livakos & EURE & 0.222 & Livakos & EURE & 0.304 \\
\hline Gerakarou & EURE & 0.2 & Gerakarou & EURE & 0.284 \\
\hline Mosbach 5 & EURW & 0.2 & Mosbach 5 & EURW & 0.284 \\
\hline Apollonia & EURE & 0.143 & Dmanisi & EURE & 0.233 \\
\hline Dmanisi & EURE & 0.143 & St Vallier & EURW & 0.233 \\
\hline St Vallier & EURW & 0.143 & France MNQ20 & EURW & 0.225 \\
\hline Vergranne & EURW & 0.143 & Apollonia & EURE & 0.188 \\
\hline France MNQ20 & EURW & 0.133 & Vergranne & EURW & 0.188 \\
\hline Chilhac & EURW & 0.1 & Chilhac & EURW & 0.112 \\
\hline Senèze & EURW & 0.059 & Senèze & EURW & 0.108 \\
\hline
\end{tabular}

